\title{
Amazon aquatic biodiversity imperiled by oil spills
}

\author{
Valter M. Azevedo-Santos ${ }^{1} \cdot$ James R. Garcia-Ayala $^{1} \cdot$ \\ Philip M. Fearnside ${ }^{2}$. Francisco A. Esteves ${ }^{3}$. \\ Fernando M. Pelicice ${ }^{4}$ - William F. Laurance ${ }^{5}$. \\ Ricardo C. Benine ${ }^{1}$
}

Received: 7 April 2016/Revised: 28 June 2016/Accepted: 12 August 2016/ Published online: 13 September 2016

(C) Springer Science+Business Media Dordrecht 2016

\begin{abstract}
Oil exploitation poses a significant threat to freshwater biodiversity, and future plans to develop petroleum leases in the Amazon Basin should be seem with caution. A series of oil spills have significantly affected biodiversity and human activities in some Amazonian basins, indicating that disturbances by petroleum activities will increase in the region, particularly in upper basins and river headwaters. Measures are needed to reduce the risk of spills and to minimize their impacts. More fundamentally, changes in decision making are needed that give proper weight to these impacts.
\end{abstract}

Keywords Petroleum · Pollution · Fish kill · Environmental impact · Freshwater · Development policy

Communicated by Jefferson Prado.

This article belongs to the Topical Collection: Coastal and marine biodiversity.

Valter M. Azevedo-Santos

valter.ecologia@gmail.com

1 Laboratório de Ictiologia, Departamento de Zoologia, Universidade Estadual Paulista "Júlio de Mesquita Filho", Botucatu, SP 18618-970, Brazil

2 Instituto Nacional de Pesquisas da Amazônia (INPA), Manaus, AM 69067-375, Brazil

3 Núcleo em Ecologia e Desenvolvimento Sócio Ambiental de Macaé, Universidade Federal do Rio de Janeiro, Macaé, RJ 27965-045, Brazil

4 Núcleo de Estudos Ambientais, Universidade Federal de Tocantins, Porto Nacional, TO 77500-000, Brazil

5 Centre for Tropical Environmental and Sustainability Science (TESS) and College of Marine and Environmental Sciences, James Cook University, Cairns, QLD 4878, Australia 
The remarkable biodiversity of Amazon Rivers is imperiled by a growing number of threats such as hydropower expansion (e.g. the Belo Monte dam) (Lees et al. 2016; Val et al. 2016; Winemiller et al. 2016), deforestation (e.g. Brazil's newly weakened Forest Code) (Soares-Filho et al. 2014), mining (Meira et al. 2016), and direct pollution by petroleum activities (Kimerling 2013). This last threat, in particular, has been largely overlooked by authorities.

Recently, the leakage of 3000 barrels of oil in the Peruvian Amazon contaminated the Marañon River, a major tributary of the Amazon River (Mega 2016). This is far from an isolated case; for instance, an oil spill in 2014, in the same region, caused significant biological and water deterioration, affecting the well-being of local people (Fraser 2014). Other parts of the Amazon region have been affected by oil spills, including the Texaco/ Chevron oil projects in Ecuador that released oil over a period of almost 30 years (e.g. Jochnick et al. 1994; Kimerling 2006). Ecuador continues to be a major source of oil pollution in Amazonia, including spills from ongoing oil projects in the Yasuni National Park (Kimerling 2013) and a spill on an Amazon tributary in Ecuador that carried oil to both Peru and Brazil (BBC News 2013). Large areas are slated for future oil development (Finer et al. 2008; Castello and Macedo 2016), indicating that disturbances by petroleum activities will increase in the region, particularly in upper basins and river headwaters. This is troubling because the connectivity and unidirectional water flow in lotic environments will spread the disturbance across downstream sections of the system (e.g. wetlands).

Oil spills have high potential to negatively affect freshwater aquatic ecosystems and can severely affect biodiversity (Steen et al. 1999). Oil affects aquatic invertebrate and vertebrate fauna both directly by toxicity and indirectly by decreasing oxygen diffusion (Lytle and Perckarsky 2001; Couceiro et al. 2006). In the 2014 oil spill in the Marañon River, a massive amount of fish was killed immediately (Fraser 2014). This fish kill probably affected other organisms, since fish are common prey for caimans, birds and mammals. Community and food web structure may remain disrupted for years as a result of spills (Kingston 2002). Spilled oil has multiple consequences for humans, including severe impacts on health (see review by Chang et al. 2014). Disturbances like these, therefore, can compromise water resources and services, including drinking water and fisheries.

These impacts imply a need for changes at many levels in Amazonian countries. Measures are needed to provide alerts to environmental authorities and development planners. Implementing a system to monitor water quality and pollution levels is a minimum first step towards promoting policy action. Amazonian countries must establish sustainable limits to the geographical expansion of petroleum activities. Development plans should avoid oil leases in hydrographic basis and river stretches that provide essential services (e.g. fisheries, wetlands, nutrient cycling) or that have high endemic biodiversity. In addition, inspection of existing leases must be carried out on a permanent basis, and irregular activities must be effectively repressed.

Most importantly, fundamental changes are needed in the decision-making process to arrive at rational decisions on oil development (or on any other form of development). These decisions need to be made with information on environmental and social impacts in hand and with institutional mechanisms for democratic discussion of the issues involved before the decision to implement a project is made in practice. Unfortunately, this is not yet the case in any of the Amazonian countries. The recent history of Amazonian hydroelectric dams provides clear examples of the lack of such a procedure and order of events in Brazil (Fearnside 2014, 2015). The same applies to other Amazonian countries, such as Peru (Vega 2010). Authorities in the Amazonian countries must reconsider the unprecedented development schemes planned for the Amazon Basin, which will cause extensive changes 
in hydrology, land use and water quality. The international community could and should be actively engaged in these agendas, particularly because the Amazon provides services at the global scale (e.g. climate).

The Amazon Basin is home to a rich biodiversity with many rare, endemic and unknown species, and this diversity is extremely vulnerable to large-scale human actions (Castello et al. 2013; Lees et al. 2016; Val et al. 2016; Winemiller et al. 2016). Expansion of petroleum leases will aggravate this scenario (Castello et al. 2013; Castello and Macedo 2016). If the current trend continues, Amazonian aquatic biodiversity-probably the richest on Earth—will experience large-scale and irreversible losses in a short time period.

\section{References}

BBC News (2013) Brazil 'on alert' over an oil spill from Ecuador. BBC News. http://www.bbc.com/news/ world-latin-america-22836975. 10 June 2013

Castello L, Macedo MN (2016) Large-scale degradation of Amazonian freshwater ecosystems. Glob Change Biol 22(3):990-1007. doi:10.1111/gcb.13173

Castello L, McGrath DG, Hess LL et al (2013) The vulnerability of Amazon freshwater ecosystems. Conserv Lett 6:217-229. doi:10.1111/conl.12008

Chang SE, Stone J, Demes K, Piscitelli M (2014) Consequences of oil spills: a review and framework for informing planning. Ecol Soc 19(2):26. doi:10.5751/ES-06406-190226

Couceiro SRM, Forsberg BR, Hamada N, Ferreira RLM (2006) Effects of an oil spill and discharge of domestic sewage on the insect fauna of Cururu stream, Manaus, AM, Brazil. Braz J Biol 66(1A):35-44. http://www.scielo.br/pdf/bjb/v66n1a/28975.pdf

Fearnside PM (2014) Brazil's Madeira River dams: a setback for environmental policy in Amazonian development. Water Altern 7(1):156-169. http://www.water-alternatives.org/index.php/alldoc/articles/ vol7/v7issue1/244-a7-1-15/file

Fearnside PM (2015) Brazil's São Luiz doTapajós Dam: The art of cosmetic environmental impact assessments. Water Altern 8(3):373-396. http://www.water-alternatives.org/index.php/alldoc/articles/ vol8/v8issue3/297-a8-3-5/file

Finer M, Jenkins CN, Pimm SL, Keane B, Ross C (2008) Oil and gas projects in the Western Amazon: threats to wilderness, biodiversity, and indigenous peoples. PLoS One 3(8):e2932. doi:10.1371/journal. pone.0002932

Fraser B (2014) Amazon oil spill has killed tons of fish, sickened native people. Environmental Health News. http://www.environmentalhealthnews.org/ehs/news/2014/jul/amazon-oil-spill. Accessed 18 Mar 2016

Jochnick C, Norman R, Zaidi S (1994) Rights violations in the Ecuadorian Amazon: the human consequences of oil development. Health Hum Rights 1(1):82-100. https://cdn2.sph.harvard.edu/wpcontent/uploads/sites/13/2014/03/7-Center-for-Economic-and-Social-Rights.pdf

Kimerling J (2006) Indigenous peoples and the oil frontier in Amazonia: the case of Ecuador, Chevron/ Texaco, and Aguinda v. Texaco. Int Law Politics 38:43-115. http://nyujilp.org/wp-content/uploads/ 2013/02/38.3-Kimerling.pdf

Kimerling J (2013) Oil, contact, and conservation in the Amazon: indigenous Huaorani, Chevron, and Yasuni. Colo J Int Environ Law Policy 24(1):43-115. http://papers.ssrn.com/sol3/papers.cfm?abstract_ $\mathrm{id}=2332782$

Kingston PF (2002) Long-term environmental impact of oil spills. Spill Sci Technol Bull 7:53-61. doi:10. 1016/S1353-2561(02)00051-8

Lees AC, Peres CA, Fearnside PM, Schneider M, Zuanon JAS (2016) Hydropower and the future of Amazonian biodiversity. Biodivers Conserv 25:451-466. doi:10.1007/s10531-016-1072-3

Lytle DA, Perckarsky BL (2001) Spatial and temporal impacts of a diesel fuel spill on stream invertebrates. Freshw Biol 46(5):693-704. doi:10.1046/j.1365-2427.2001.00695.x

Mega ER (2016) Oil spills stain Peruvian Amazon. Scientific American. http://www.scientificamerican.com/ article/oil-spills-stain-peruvian-amazon/. Accessed 4 Mar 2016

Meira RMSA, Peixoto AL, Coelho MAN et al (2016) Brazil's mining code under attack: giant mining companies impose unprecedented risk to biodiversity. Biodivers Conserv 25:407-409. doi:10.1007/ s10531-016-1050-9

Soares-Filho B, Rajão R, Macedo M et al (2014) Cracking Brazil's forest code. Science 344:363-364. doi: $10.1126 /$ science. 1246663 
Steen A, Fritz DE, Stubblefield W, Giddings J (1999) Environmental effects offreshwater oil spills. In: International Oil Spill Conference Proceedings 1999:607-612

Val AL, Fearnside PM, Almeida-Val VMF (2016) Environmental disturbances and fishes in the Amazon. J Fish Biol 89:192-193. doi:10.1111/jfb.12896

Vega JS (2010) Inambari: La urgencia de una discusión seria y nacional: Pros y contras de un proyecto hidroeléctrico. ProNaturaleza-Fundación Peruana para la Conservación de la Naturaleza, Lima, Peru

Winemiller KO, McIntyre PB, Castello L et al (2016) Balancing hydropower and biodiversity in the Amazon, Congo, and Mekong. Science 351:128-129. doi:10.1126/science.aac7082 